\title{
Selecting client's project control strategies in person-to-organization transactions
}

\begin{abstract}
:
Selection of inter-personal and inter-organizational control strategies has been widely examined. However, it is not known whether the findings could be generalized to the person-to-organization relationship setting. Taking dwelling fit-out projects as the empirical setting, this study aims to investigate client's project control strategy selection in person-to-organization transactions. A questionnaire-survey of clients who had completed a dwelling fit-out project before was carried out in China. This study re-affirms that project quality ambiguity would decrease outcome control; project-related knowledge facilitates behavior control. Additional insights are obtained that perceived legal enforceability has positive impacts, whereas quality performance ambiguity has negative impacts, on social controls. Perceived legal enforceability is positively associated with outcome and behavior controls. This study contributes to the literature of project control strategy selection by adding a new antecedent of perceived legal enforceability and extends the findings to the person-to-organization transactions. Implications for project controls are provided in the end.
\end{abstract}

\section{Key words:}

Control; person-to-organization; quality performance ambiguity; legal enforceability; China 


\section{Introduction}

Formal and informal controls are common methods for managing projects (e.g., Choudhury \& Sabherwal, 2003; Gyawali, Tao, \& Müller, 2013; Kirsch, 1997; Nieminen \& Lehtonen, 2008; Tuuli, Rowlinson, \& Koh, 2010). Prior studies examined the drivers and consequences of control strategies (Liu, 2015; Liu \& Deng, 2015; Liu \& Wang, 2015; Tuuli, Rowlinson, \& Koh, 2010), the interplay between formal and informal controls (Piccoli \& Ives, 2003) and portfolio of control strategies (Choudhury \& Sabherwal, 2003; Kirsch, 1997). One key theme of the research stream is to investigate the conditions under which the control strategies are appropriate to cope with project hazards (e.g., Kirsch, Sambamurthy, Ko, \& Purvis, 2002; Stump and Heide, 1996).

The selection of control strategies could be explained by the control theory (Eisenhardt, 1985) and transaction cost economics (TCE) theory (Williamson, 1985). In the control theory, the choice of control strategies depends on project characteristics (i.e., task programmability and output measurability) (Eisenhardt, 1985) and controller's knowledge (Kirsch et al., 2002; Turner \& Makhijia, 2006). TCE provides another lens to look into project characteristics, arguing that transaction costs depend on a combination of three project features, namely asset specificity, uncertainty and transaction frequency (Dekker, 2004). These two theories mainly consider project characteristics and control strategies as independent and dependent variables respectively.

Although control strategy selection highlights project characteristics and project-related knowledge (e.g., Ning and Ling, 2014; Turner \& Makhijia, 2006), we know little about how perceived legal enforceability influence control strategies (Bai, Sheng \& Li, 2016; Wang, Zhang, Wang, \& Sheng, 2016). This study seeks to provide a more nuanced understanding of control strategy selection through exploring how project characteristics (i.e., quality performance ambiguity), project-related knowledge and perceived legal enforceability influence control strategy selection. Quality performance ambiguity is highlighted as it is often companied with shirking and opportunism in the project development (Gray and Handley, 2015), which requires appropriate control strategy to cope with. Insights on the influence of regulatory 
context on control strategy selection would inform actors the distinction between different institutional systems.

Although the selection of project control strategies has been widely examined in the inter-personal and inter-organizational relationships (e.g., Kirsch, 1997, Nieminen and Lehtonen, 2008), it is not known whether the findings could be generalized to the person-to-organization project settings. Prior studies found the project-related knowledge is an important antecedent of control strategy selection (Kirsch et al., 2002). However, individual clients face greater knowledge deficiency than their partner in terms of project development, contract design and application. This knowledge deficiency would result in strong information asymmetry, which is a significant contributor to opportunistic behaviors (Das and Kumar, 2010). Thus, it would be significantly worthwhile to investigate how clients select project control strategies in person-to-organization business. A better understanding of the pattern of control strategy selection in person-to-organization projects would help the client to manage the relationship properly.

The dwelling fit-out projects in China was investigated as the empirical setting. In dwelling fit-out projects, controller is the individual client (i.e., personal level) and controlees are the appointed contractor (i.e., organizational level). The distinction of projects governed by person-to-organization relationships serves as the frame for this study. China's context is highlighted because China as an emerging market is experiencing a painful transition from relation-based to rule-based governance $(\mathrm{Li}$, 2013). It is recognized that a stable legal institution for enforcing contract law nation-wide has not been established thus far (Luo, 2007). Thus, it would be imperative to examine whether the institutional environment would influence project control strategy selection.

The paper is organized as follows. Section two presents literature about three control strategies (i.e., outcome control, behavior control and social control) and selection of control strategies. It is followed by a section reporting the conceptual framework and hypothesis development. The research method of a questionnaire-survey is presented in Section four. Statistic results are presented in Sections five and six. Discussion and conclusion are shown in the end. 


\section{Literature review}

\subsection{Control strategies}

Control is defined as 'a regulatory process by which the elements of a system are made more predictable through the establishment of standards in the pursuit of some desired objective or state' (Leifer and Mills 1996: 117). There are two broad categories of control mechanisms: formal control and social control (Das \& Teng, 2001; Dyer and Singh, 1998).

In exchanges, formal control relies on the completeness and importance of contracts (Li, Xie, Teo, \& Peng, 2010). It establishes rules or norms for actors' behaviors; monitors actors' work through surveillance methods (Eisenhardt, 1985), and compares outcomes or behaviors with pre-determined ones. The tools used to curtail contractor's shirking and opportunism propensity are inspection, monitoring and failure penalties. There are two main modes of formal control: outcome control and behaviour control. Outcome control relies on the assessment of the performance, while behaviour control focuses on the process (Das \& Teng, 2001).

\section{1) Outcome control}

Outcome control mechanisms specify outcomes to be realized and monitor the achievement of these targets (Dekker, 2004). The controller explicitly states desired outcomes and rewards the controlee based on the achievement of those goals (Choudhury \& Sabherwal, 2003; Eisenhardt, 1985). Thus, outcome control relies on mechanisms that could specify desired outcome and measure the controlee's performance with respect to the specific outcome. Incentives are clearly aligned with a desired outcome (Turner \& Makhija, 2006).

\section{2) Behavior control}

Behavior control mechanisms specify how controlee should act and monitor whether actual behaviors comply with the pre-specified behaviors (Dekker, 2004). Behavior control is featured by behavior monitoring and rewards (Dekker, 2004). Controller could prescribe specific rules and procedures, observe the controlees' behaviors, and 
reward the controlee based on the extent to which it follows pre-determined procedures (Kirsch, 1996).

Behavior controls encompass formalized standard, operating procedures, rules and routines (Abubakre, Ravishankar, \& Coombs, 2015). Abdi \& Aulakh (2014) found that behavior control would be effective to prevent behavioural uncertainty (i.e., the inadequate common grounds and shared frameworks among controller and controlee).

\section{3) Social control}

Social control comprises risk taking, joint decision making and problem solving (Dekker, 2004). Formal controls tend to present a mechanistic view of the control process. But they ignore inter-personal mechanism that governs behaviors (Ashford \& Tsui, 1991). Relationships built among actors can serve as informal control tools. Social control mechanism could govern partnership behaviours (Rowley, Behrens, \& Krackhardt, 2000), through promoting trust, mutual gain and reciprocity (Larson, 1992). Social control enables actors to coordinate functions and work out problems "on the fly" (Uzzi, 1997).

Prior studies found that the social controls have close interaction with the formal controls (e.g., Bygballe, Dewulf, \& Levitt, 2014; Cao \& Lumineau, 2015; Gregory, Beck, \& Keil, 2013) and the adoption of the social control mechanism could give rise to better project outcomes (e.g., Ning, 2014). Formal control and social control may substitute or complement each other. The reasons for the substituting effect could be manifested by "replacing" and "dampening"; the reasons for complements are summarized as "compensating" and "enabling" (Huber et al., 2013).

\subsection{Selection of control strategies}

Selection of control strategies could be explained by the control theory and transaction cost economics theory (see a review of Crosno \& Brown, 2015). In the control theory, Eisenhardt (1985) suggested that the choice of an appropriate control strategy depends on two project characteristics: task programmability and output measurability.

Task programmability refers to the degree to which managers understand the transformation process in which appropriate behaviours would take place (Das \& Teng, 
2001). Task programmability is strongly related to the choice of compensation package. Output measurement ambiguity indicates the difficulty of defining ex ante and verifying ex post the products and services procured in the contract (Anderson \& Dekker, 2005). When the performance is difficult to measure, controlees would have incentives to limit their efforts, because controller cannot accurately measure or reward the outcome (Zhou \& Poppo, 2010).

The main tenet of TCE is to "align transactions, which differ in their attributes, with governance structures, which differ in their costs and competencies, in a discriminating way" (Williamson, 1991: 279). Transaction costs depend on a combination of three project characteristics (i.e. asset specificity, uncertainty and frequency) (Dekker, 2004). van Fenema \& Loebbecke (2014) argued that the lower the level of project uncertainty and interdependence, the more controllers would adopt formal controls rather than social control to cope with the hazards.

\section{Conceptual framework and hypothesis development}

The conceptual framework is shown in Figure 1. Specific hypotheses are elaborated below.

\section{<Insert Figure 1 here $>$}

\subsection{Project-related knowledge}

Outcome controls need to specify outcomes in a manner that affords little uncertainty over the outcome measurement (Turner \& Makhija, 2006). This requires that controller should have complete outcome-related knowledge. Prescribing specific behaviors in behavioral control is also knowledge-based; the controller must believe that it knows better than the controlee the optimal process to follow in the specific context of project (Choudhury and Sabherwal, 2003).

Prior studies found that controller's project-related knowledge facilitates behavior control (e.g., Eisenhardt, 1985; Kirsch et al., 2002). Knowledgeable controller would be more confident to specify the exact process the controlee should follow (Choudhury and Sabherwal 2003). Thus, it is hypothesized that: 
H1: Clients those who have a higher level of project-related knowledge would implement (a) outcome control, (b) behaviour control and (c) social control to a greater extent.

\subsection{Perceived legal enforceability}

Legal enforceability refers to "the extent to which the enforcement of legislation and regulations is effective and the legal framework is complete in providing protection for economic transactions" (Bai et al., 2016: 13). When legal frameworks fail to protect client's interests, unlawful behaviors (e.g., contract violations) might prevail (Ho 2001). This is because it is difficult to execute the legal process to protect against unlawful behaviors (McMillan and Woodruff, 1999).

Under this circumstance, client might resort to the social controls. Sheng et al. (2011) supported that business ties are beneficial when legal enforcement is inefficient. Zhou and Poopo (2010) reinforced that when managers do not perceive the legal system as credible, they would resort to relational reliability to safeguard transactions. When managers perceive that legal system can protect their firm's interests, they tend to use explicit contracts rather than relational reliability to safeguard hazards. Thus, the hypotheses are set out as:

H2: Clients those who perceive legal enforceability to a higher extent would adopt (a) outcome control and (b) behavior controls to a higher extent; and (c) social controls to a lower extent.

\subsection{Quality performance ambiguity}

Performance ambiguity is referred to "the inherent difficulty faced by the buyer in accurately evaluating the supplier's performance" (Stump and Heide, 1996:436). High performance ambiguity indicates inherent difficulties in assessing controlees' product and service performance (Anderson \& Dekker, 2005; Gray and Handley, 2015) and contractual compliance (Carson et al., 2006; Stump and Heide 1996). Therefore, controlees would limit their efforts (Zhou \& Poppo, 2010), thereby problems of potential shirking might arise (Mooi \& Ghosh, 2010; Wathne \& Heide, 2000). This would increase client's hazards. 
Three dimensions would contribute to quality performance ambiguity: low testability, low monitorability, and low root-cause assignability (e.g., Eisenhardt, 1985; Gray and Handley, 2015). As quality performance ambiguity increases, the link between quality performance and rewards would be difficult to build (Mayer and Salomon, 2006). Therefore, contractors would shirk in activities that affect project quality.

To cope with potential problems, formal controls might be a possible solution. For example, contracts may include provisions (i.e., extensive descriptions of roles and responsibilities) for monitoring contractor's behaviors (Argyres \& Mayer, 2007). The formal approaches provide a benchmark against which contractor's behaviors can be judged to involve shirking or not.

However, as the environment becomes complex, it would lead to problems relating to incompleteness of contract (Argyres \& Mayer, 2007). Thus, it is argued that quality performance ambiguity may inhibit formal controls. Low testability and/or a lack of root cause assignability render great difficulties in linking quality outcome to contractor's rewards. This would in turn result in contractor's performance shirking. Low monitorabilty would also impede the effectiveness of inspects and checks, because it would complicate the link between observed behaviors and quality outcomes (Turner \& Makhija, 2006). As the formal controls would be crowded out, clients would be inclined to adopt social controls to safeguard their interests. Thus, the hypotheses are set out as:

H3: A higher level of quality performance ambiguity is associated with a lower level of (a) outcome control and (b) behavior control, and a higher level of (c) social control.

\section{Research methods}

\subsection{Research setting}

We selected dwelling fit-out project controls in China as our empirical context. Fit-out refers to the process of making interior spaces suitable for occupation. The base construction is completed by the developer, and the final fit out by the occupant.

Occupant (i.e. the client) appoints a decoration company as the contractor to undertake 
the final fit-out works. The work package may comprise interior design, construction, supply of construction material, furniture, finishes and equipment, and maintenance.

\subsection{Sampling}

Clients who had the experience of dwelling decoration before were approached using the purposing sampling strategy given that no official directories are available. The sample strategy might not render biased and skewed results as the sample covers a broad spectrum of family incoming, age, industries, dwelling areas, project amount and duration (see Table 1).

A total of 348 survey questionnaire were sent out between May and July 2016 with the help of local decoration association. Of these, 264 responses were received, giving a response rate of $84.6 \%$. Such a higher response rate was attributed to two reasons. First, the local decoration association provided reliable contact information. Second, face-to-face interviews were adopted to collect the questionnaires. Despite its time-consuming, this method was effective to generate high-quality information and high response rate.

\subsection{Measurements}

The procedures recommended by Gerbing and Anderson (1988) were adopted to develop the questionnaire. First, 94 cases studies were initially carried out to understand industry practices. The case studies revealed that controls are important in dwelling fit-out projects. But, client still failed to manage it properly. The dwelling decoration business is one of the low-trust sectors in China. Combining with prior studies, an initial questionnaire was developed. Second, 25 in-depth interviews with representatives from decoration companies and clients were undertaken to further refine the questionnaire. Third, the questionnaire items were pretested with six clients who had dwelling decoration experience. Feedbacks were elicited to clarify the measurement instruments and appropriateness of the terminologies. After the pre-test, the questionnaire was refined and finalized.

All the measurement items were measured with a 5-point Likert scale (1=strongly disagree; $5=$ strongly agree). Four indicators were used to measure quality performance ambiguity, adapted from Gray and Handley (2015). These are: 1) it is difficult to 
observe all quality problems through inspecting and monitoring; 2) it is difficult to determine whether quality problem is attributable to the contractor; 3 ) it is difficult to assess whether contractor is compliance with the contractual procedures and construction methods; and 4) it is difficult to assess whether the information provided by the contractor is reliable.

Project-related knowledge. Since there are no established measurements available for the dwelling fit-out projects, the measurement of project-related knowledge was newly developed based on the case study and interview results. It comprised: 1) I have sufficient knowledge about the finishes, materials; 2) I have sufficient knowledge about the construction method; 3) I have sufficient knowledge about the operational procedures of dwelling fit-out projects.

Perceived legal enforceability was operationalized as: 1) when conflicts arise, the legal system protects my interests; and 2) the legal system could restrain contractor's cheating and fraud behaviors (Zhou \& Popp, 2010).

Outcome control was manifested by: 1) I specify the performance standards in contract which is seen as the basis for monitoring; 2) I specify the deadlines which are seen as basis for controlling; and 3) I strictly control and monitor the accomplishment of the targets (Heide, Wathne, \& Rokkan, 2007).

Behavior control was adapted from (Heide et al., 2007) and operationalized as: 1) I check all material brands and quality delivered to the site in person; 2) I go to site frequently in order to monitor contractor's behaviors; 3) I request the contractor to update progress information on a regular basis.

Social control was adapted from Li et al. (2010) and Heide \& Miner (1992). It was assessed by asking the respondents to indicate whether control was exercised through: 1) participatory decision-making; 2) joint problem solving; 3) fine-grained information exchange; 4) when some unexpected situation arises, we would rather work out a new deal than hold each other to the original terms; 5) we are open to modifying the agreements if unexpected events occur. 
All constructs and associated measurement were refined before hypothesis testing through a confirmative factor analysis. Partial Least Square-Structural Equation Modeling (PLS-SEM) was selected because it is able to identify key driving constructs (Hair et al., 2011; Ringle et al., 2012), and has minimum demand for sample size (Reinartz et al., 2009).

\section{Descriptive results}

The profile of the respondents and their projects are presented in Table 1. The results show that two thirds of the respondents are males. The majority of the respondents are of the age below 40, indicating that this generation is major force in the property purchase market. Over half respondents indicated that they have three or fewer number of family members.

The results show that nearly half of contractors are medium-size firms. The vast majority respondents chose local companies. Over half of the dwelling fit-out projects are of medium complexity, over $60 \%$ being below $120 \mathrm{~m}^{2}$, over half being below 130 thousand RMB, $65 \%$ of a construction period less than three months.

\section{<Insert Table 1 here>}

\section{Model evaluation}

\subsection{Measurement model evaluation}

Tables 2 to 4 show the evaluation results of the measurement models. Table 2 shows that all loadings are greater than 0.50 with $\mathrm{t}$-values greater than 2.58 (Hulland 1999). This indicates acceptable indicator reliability. A high level of reliability of internal indicators within each factor was obtained as the values of composite reliability (CR) are over 0.7 (Bagozzi and Yi, 1988).

A satisfactory level of convergent validity of the factors was achieved by examining the values of the average variance extracted (AVE) more than 0.5. Two indicators were used to assess discriminate validity. The AVE of each factor is higher than its squared correlation with any other factors (see Table 3), and each measurement item has the highest loading on the corresponding factor (see Table 4). These together indicate a satisfactory discriminate validity of the factors (Fornell and Larcker, 1981). 
After LS-SEM, these results reveal that the measures in this study possess adequate reliability and validity.

\section{<Insert Tables 2 to 4 here>}

\subsection{Structural model evaluation and hypothesis testing}

Table 5 presents structural model evaluation and hypothesis testing results. The results show that six of nine path coefficients have a t-value greater than 1.96, indicating they are statistically significant at the 0.05 level. Four hypotheses (i.e., $\mathrm{H}_{1 \mathrm{~b}}, \mathrm{H}_{2 \mathrm{a}}, \mathrm{H}_{2 \mathrm{~b}}$ and $\mathrm{H}_{3 \mathrm{a}}$ ) are supported, while two hypotheses (i.e., $\mathrm{H}_{2 \mathrm{c}}$ and $\mathrm{H}_{3 \mathrm{c}}$ ) are not supported in the hypothesized sign.

\section{<Insert Table 5 here>}

\section{Discussion}

\subsection{Effects of project-related knowledge on control strategies}

The results show that project related knowledge would increase the implementation of behavior control $\left(\mathrm{H}_{1 \mathrm{~b}}\right)$. This is in line with prior studies (e.g., Turner \& Makhija, 2006) that client's understanding of project development is a key factor of determining behavior control. A controller with greater knowledge of appropriate behaviors may be more likely to implement behavior controls (Kirsch, 1997). Choudhury and Sabherwal (2003) explained that knowledgeable controller would be more confident to specify the exact process the controlee should follow.

The results show that project-related knowledge has no significant impact on outcome $\left(\mathrm{H}_{1 \mathrm{a}}\right)$ and social controls $\left(\mathrm{H}_{1 \mathrm{c}}\right)$. Due to bounded rationality, it is almost impossible for client to anticipate appropriate performance standards. During the project, clients might also propose various change orders, which would influence the cost and schedule target as stipulated in advance. The project-related knowledge would hardly facilitate outcome controls.

Project-related knowledge has no significant impact on social controls because social control promotes trust, mutual gain and reciprocity (Larson, 1992). Building a relational contract requires developing a shared understanding of not only the 
necessary task knowledge (i.e., what each party is supposed to do) but also the necessary relational knowledge (i.e., what each party could do) (Gibbons \& Henderson, 2012).

\subsection{Effects of perceived legal enforceability on control strategies}

The study found that perceived legal enforceability would increase the adoption of outcome $\left(\mathrm{H}_{2 \mathrm{a}}\right)$ and behavior control $\left(\mathrm{H}_{2 \mathrm{~b}}\right)$. This is in agreement with Zhou and Poppo (2010) that when managers perceive that the legal system can protect their interests, they tend to use explicit contracts to safeguard transactions. Legal systems underpin contract enforcement (Zhou and Poppo, 2010) and protect clients against contractual violations (McMillan and Woodruff, 1999).

Outcome and behavior controls specify outcome and behavior targets and reward contractor based on the actual outcome and behavior performance (Eisenhardt, 1985). An effective legal system imposes regulatory pressures on contractor to follow the standards. Therefore, it protects clients from contactor's potential denial of responsibility (Bai et al., 2016).

The study found that perceived legal enforceability is positively associated with the adoption of social control $\left(\mathrm{H}_{2 \mathrm{c}}\right)$. This is inconsistent with Zhou and Poppo (2010) who found that when managers do not perceive the legal system as credible, they would resort to relational reliability to safeguard transactions. This might be because when clients believe that the legal framework could protect their best interests, they would have great confidence to implement participatory decision-making, joint problem solving and information sharing. Compared to inter-organizational relationships, clients in person-to-organizational relationships are less powered to bargain with the contractor within the legal framework. Thus, legal enforceability would reinforce their confidence about social controls.

\subsection{Effects of project quality ambiguity on control strategies}

Consistent with prior studies (e.g., Argyres \& Mayer, 2007; Holmstrom and Milgrom, 1991), the results reinforced that project quality ambiguity would decrease the use of outcome control $\left(\mathrm{H}_{3 \mathrm{a}}\right)$. Outcome control is achieved through specifying desired outcomes (e.g., functional requirements, milestones and cost target) and mechanisms 
that help measure the controlee's performance with respect to the specific outcome (Choudhury \& Sabherwal, 2003). Outcome control would be effective when there is little uncertainty over the ideal outcome (Turner \& Makhija, 2006). If the output quality of a project is difficult to verify, outcome-based contract would be problematic (Holmstrom and Milgrom, 1991). High quality performance ambiguity indicates low testability, low monitorability, and low root-cause assignability (e.g., Gray and Handley, 2015). This would bring about significant difficulties in specifying desired outcomes.

The results showed that quality performance ambiguity is negatively associated with use of social control $\left(\mathrm{H}_{3 \mathrm{c}}\right)$. This is because low testability, low monitorability, and low root-cause assignability would increase client's vigilance and watchfulness. Client would distrust contractor's intentions and behaviors. Therefore, they would be less likely to adopt social controls.

The results showed that quality performance ambiguity has no significant impact on behavior controls $\left(\mathrm{H}_{3 b}\right)$. This might be because the performance ambiguity indicates the difficulty of defining product or service performance in contract (Anderson \& Dekker, 2005). However, the behavior controls require clients to specify the process to achieve the outcome clearly, and the specific process is featured by less complexity (Turner \& Makhija, 2006).These two controls have different focus and conditions.

\section{Conclusions}

This study examined the conditions under which clients choose various control strategies. Prior studies mainly examined the inter-personal and inter-organizational control strategies. This study extended the findings to the person-to-organization control domain. Dwelling fit-out projects were selected as the empirical setting. Questionnaire-survey of clients who had completed dwelling fit-out project before was carried out.

\section{The theoretical implication of this study is two-fold. First, this study extended the selection of control strategy literature to the person-to-organization domain and verified prior findings on how project quality ambiguity and project-related} knowledge influence control strategy adoption. The study both confirmed prior results 
and offered additional insights. Consistent with prior studies, this study re-affirmed that in person-to-organizational transactions, project-related knowledge would increase the implementation of behavior control; project quality ambiguity decreases the use of outcome control. One important finding is found to contradict with extant studies: project quality ambiguity would decrease client's social control.

Second, this study contributed to the literature of control strategy selection by adding a new antecedent of perceived legal enforceability. The results showed that perceived legal enforceability is positively associated with outcome, behavior and social controls. Those three antecedents together presented greater explanatory power in the project control strategy selection.

The research provided important practical implications for project controls. First, it is found that only project-related knowledge would strength client's confidence on adopting behavior control, whereas project quality ambiguity would deter them from outcome and social controls. Thus, in order to manage the project effectively, having sufficient knowledge about the dwelling fit-out projects might be a solution. Clients could absorb knowledge by their own capability (e.g., study know-hows from other clients who have relevant experience and reading relevant references) or appoint a third-party to make up their weakness. The second practical implication is for the policy and regulation formulation. The results show that perceived legal enforceability plays an important role in nurturing outcome, social and behavior controls. Thus, it is important for the government to reinforce the regulatory structure to protect client's best interests.

The results should be interpreted in the context of study limitations. First, this study focused on dwelling fit-out projects as one specific type of person-to-organization context. Future studies could generalize the findings to other empirical context. Second, this study elicited client's feedbacks on control strategies. Further study can collect the information on dyadic relationships between client and contractors. This would further substantiate the research findings. Last, China is experiencing a transition from a planned economy to a market economy. Thus, the specific regulatory context and client's perception of the legal enforceability would be similar to other 
emerging economics, but different from the western countries. Thus, it would be interesting to carry out cross-nation comparative studies. 


\section{References}

Abdi, M., \& Aulakh, P. S. (2014). Locus of uncertainty and the relationship between contractual and relational governance in cross-border interfirm relationships. Journal of Management, 0149206314541152.

Abubakre, M. A., Ravishankar, M. N., \& Coombs, C. R. (2015). The role of formal controls in facilitating information system diffusion. Information \& Management, 52(5), 599-609.

Anderson, S. W., \& Dekker, H. C. (2005). Management Control for Market Transactions: The Relation Between Transaction Characteristics, Incomplete Contract Design, and Subsequent Performance. Management Science, 51(12), 1734-1752.

Argyres, N., \& Mayer, K. J. (2007). Contract design as a firm capability: An integration of learning and transaction cost perspectives Academy of Management Review, 32(4), 1060-1077.

Ashford, S. J., \& Tsui, A. S. (1991). Self-regulation for managerial effectiveness: The role of active feedback seeking. Academy of Management journal, 34(2), 251-280.

Bai, X., Sheng, S., \& Li, J. J. (2016). Contract governance and buyer-supplier conflict: The moderating role of institutions. Journal of Operations Management, 41, 12-24.

Bygballe, L. E., Dewulf, G. \& Levitt, R. E. (2014). The interplay between formal and informal contracting in integrated project delivery. Engineering Project Organization Journal, 5(1), 22-35.

Cao, Z. \& Lumineau, F. (2015). Revisiting the interplay between contractual and relational governance: A qualitative and meta-analytic investigation. Journal of Operations Management, 33-34, 15-42.

Carson, S. J., Madhok, A., \& Wu, T. (2006). Uncertainty, opportunism, and governance: The effects of volatility and ambiguity on formal and relational contracting. Academy of Management Journal, 49(5), 1058-1077.

Choudhury, V., \& Sabherwal, R. (2003). Portfolios of Control in Outsourced Software Development Projects. Information Systems Research, 14(3), 291-314.

Crosno, J. L., \& Brown, J. R. (2015). A meta-analytic review of the effects of organizational control in marketing exchange relationships. Journal of the Academy of Marketing Science, 43(3), 297-314.

Das, T. K., \& Kumar, R. (2010). Regulatory focus and opportunism in the alliance development process. Journal of Management.

Das, T. K., \& Teng, B. S. (2001). Trust, control, and risk in strategic alliances: An integrated framework. Organization studies, 22(2), 251-283.

Dekker, H. C. (2004). Control of inter-organizational relationships: evidence on appropriation concerns and coordination requirements. Accounting, Organizations and Society, 29(1), 27-49.

Dyer, J. H., \& Singh, H. (1998). The relational view: Cooperative strategy and sources of interorganizational competitive advantage. Academy of management review, 23(4), 660-679.

Eisenhardt, K. M. (1985). Control: Organizational and economic approaches. Management science, 31(2), 134-149.

Gerbing, D. W., \& Anderson, J. C. (1988). An updated paradigm for scale development incorporating unidimensionality and its assessment. Journal of marketing research, 186-192.

Gibbons, R., \& Henderson, R. (2012). Relational contracts and organizational capabilities. Organization Science, 23(5), 1350-1364.

Gray, J. V., \& Handley, S. M. (2015). Managing contract manufacturer quality in the presence of performance ambiguity. Journal of Operations Management, 38, 41-55.

Gregory, R. W., Beck, R. , \& Keil, M. (2013). Control balancing in information systems development offshoring projects. MIS Quarterly, 37(4), 1211-1232.

Gyawali, P., Tao, Y., \& Müller, R. (2013). Project control mechanisms in non-project-based organisations in Asia. International Journal of Project Organisation and Management, 5(4), 312-333.

Fornell, C. G., and Larcker, D. F. (1981). Evaluating structural equation models with unobservable variables and measurement error. Journal of Marketing Research, 18(1), 39-50. 
Hair, J.F., Ringle, C.M. and Sarstedt, M. (2011) PLS-SEM: indeed a silver bullet. Journal of Marketing Theory and Practice, 19(2), 139-151.

Heide, J. B., \& Miner, A. S. (1992). The Shadow of the Future: Effects of Anticipated Interaction and Frequency of Contact on Buyer-Seller Cooperation. The Academy of Management Journal, $35(2)$.

Heide, J. B., Wathne, K. H., \& Rokkan, A. I. (2007). Interfirm monitoring, social contracts, and relationship outcomes. Journal of Marketing Research, 44(3), 425-433.

Ho, S. C. (2001). Growing consumer power in China: Some lessons for managers. Journal of International Marketing, 9(1), 64-83.

Hulland, J. (1999) Use of partial least squares (PLS) in strategic management research: a review of four recent studies. Strategic Management Journal, 20(2), 195-204.

Huber, T. L., Fischer, T. A., Dibbern, J., \& Hirschheim, R. (2013). A process model of complementarity and substitution of contractual and relational governance in is outsourcing. Journal of Management Information Systems, 30(3), 81-114.

Kirsch, L. J. (1996). The management of complex tasks in organizations: Controlling the systems development process. Organization Science, 7(1), 1-21.

Kirsch, L. S. (1997). Portfolios of control modes and IS project management. Information Systems Research, 8(3), 215-239.

Kirsch, L. J., Sambamurthy, V., Ko, D. G., \& Purvis, R. L. (2002). Controlling information systems development projects: The view from the client. Management Science, 48(4), 484-498.

Larson, A. (1992). Network dyads in entrepreneurial settings: A study of the governance of exchange relationships. Administrative science quarterly, 76-104.

Leifer, R., \& Mills, P. K. (1996). An information processing approach for deciding upon control strategies and reducing control loss in emerging organizations. Journal of Management, 22(1), 113-137.

Li, S. (2013). China's (Painful) Transition from Relation - Based to Rule - Based Governance: When and How, Not If and Why. Corporate Governance: An International Review, 21(6), 567-576.

Liu, S. (2015). Effects of control on the performance of information systems projects: the moderating role of complexity risk. Journal of Operations Management, 36, 46-62.

Liu, S., \& Deng, Z. (2015). How environment risks moderate the effect of control on performance in information technology projects: Perspectives of project managers and user liaisons. International Journal of Information Management, 35(1), 80-97.

Liu, S., \& Wang, L. (2016). Influence of managerial control on performance in medical information system projects: The moderating role of organizational environment and team risks. International Journal of Project Management, 34(1), 102-116.

Li, Y., Xie, E., Teo, H.-H., \& Peng, M. W. (2010). Formal control and social control in domestic and international buyer-supplier relationships. Journal of Operations Management, 28(4), 333-344.

Luo, Y. (2007). Are joint venture partners more opportunistic in a more volatile environment?. Strategic Management Journal, 28(1), 39-60.

Mayer, K. J., \& Nickerson, J. A. (2005). Antecedents and performance implications of contracting for knowledge workers: Evidence from information technology services. Organization Science, $16(3), 225-242$.

McMillan, J., \& Woodruff, C. (1999). Interfirm relationships and informal credit in Vietnam. Quarterly journal of Economics, 1285-1320.

Mooi, E. A., \& Ghosh, M. (2010). Contract specificity and its performance implications. Journal of Marketing, 74(2), 105-120.

Nieminen, A., \& Lehtonen, M. (2008). Organisational control in programme teams: An empirical study in change programme context. International Journal of Project Management, 26(1), 63-72. 
Ning, Y. (2014). Quantitative effects of drivers and barriers on networking strategies in public construction projects. International Journal of Project Management,32(2), 286-297.

Ning, Y., \& Ling, F. Y. Y. (2015). The effects of project characteristics on adopting relational transaction strategies. International Journal of Project Management, 33(5), 998-1007.

Piccoli, G., \& Ives, B. (2003). Trust and the unintended effects of behavior control in virtual teams. MIS quarterly, 365-395.

Reinartz, W., Haenlein, M. and Henseler, J. (2009) An empirical comparison of the efficacy of covariance-based and variance-based SEM. International Journal of Research in Marketing. 26(4), 332-344.

Ringle, C.M., Sarstedt, M. and Straub, D.W. (2012) A critical look at the use of PLS-SEM in MIS quarterly. MIS quarterly, 36(1), iii-xiv.

Ringle, C.M., Wende, S. and Will, A. (2005) Smart-Pls 2.0(beta). TUHH-Hamburg University of Technology.

Rowley, T., Behrens, D., \& Krackhardt, D. (2000). Redundant governance structures: An analysis of structural and relational embeddedness in the steel and semiconductor industries. Strategic management journal, 21(3), 369-386.

Sheng, S., Zhou, K. Z., \& Li, J. J. (2011). The effects of business and political ties on firm performance: Evidence from China. Journal of Marketing, 75(1), 1-15.

Stump, R. L., \& Heide, J. B. (1996). Controlling supplier opportunism in industrial relationships. Journal of Marketing Research, 431-441.

Tenenhaus, M., Vinzi, V.E., Chatelin, Y. and Lauro, C. (2005) PLS path modeling. Computational Statistics and Data Analysis, 48(1), 159-205.

Turner, K. L., \& Makhija, M. V. (2006). The role of organizational controls in managing knowledge. Academy of Management Review, 31(1), 197-217.

Tuuli, M. M., Rowlinson, S., \& Koh, T. Y. (2010). Control modes and mechanisms in construction project teams: drivers and consequences. Construction management and economics, 28(5), 451-465.

Uzzi, B. (1997). Social structure and competition in interfirm networks: The paradox of embeddedness. Administrative science quarterly, 35-67.

van Fenema, P. C., \& Loebbecke, C. (2014). Towards a framework for managing strategic tensions in dyadic interorganizational relationships. Scandinavian Journal of Management, 30(4), 516-524.

Wang, M., Zhang, Q., Wang, Y., \& Sheng, S. (2016). Governing local supplier opportunism in China: Moderating role of institutional forces. Journal of Operations Management. doi: 10.1016/j.jom.2016.07.001

Wathne, K. H., \& Heide, J. B. (2000). Opportunism in interfirm relationships: Forms, outcomes, and solutions. Journal of Marketing, 64(4), 36-51.

Williamson, O. E. (1985). The economic intstitutions of capitalism. Simon and Schuster.

Zhou, K. Z., \& Poppo, L. (2010). Exchange hazards, relational reliability, and contracts in China: The contingent role of legal enforceability. Journal of International Business Studies, 41(5), 861-881. 


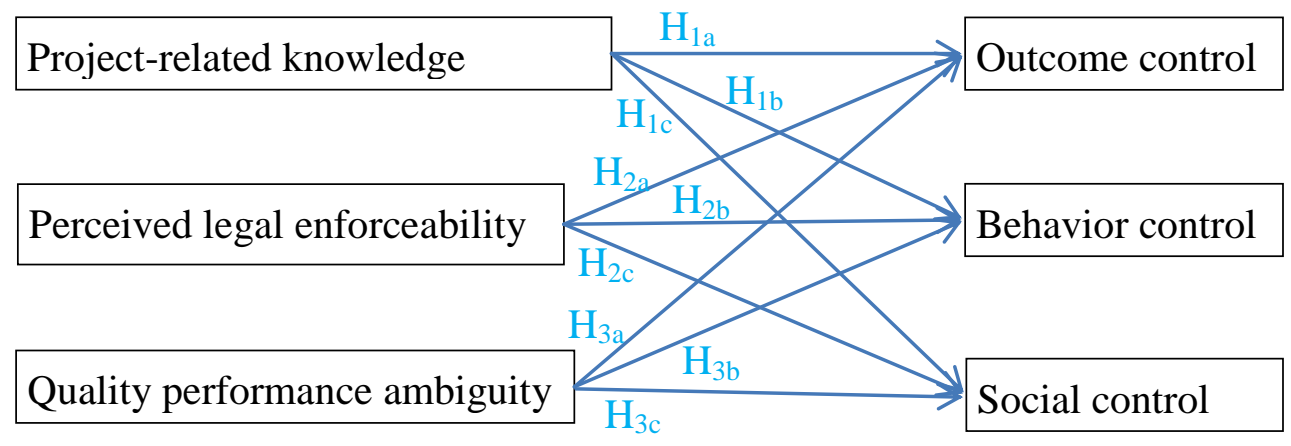

Figure 1: Conceptual framework 
Table 1: Descriptive analysis results

\begin{tabular}{|c|c|c|c|}
\hline & Measurement & Frequency & Percentage \\
\hline \multirow[t]{3}{*}{ Gender } & Male & 167 & 63.3 \\
\hline & Female & 97 & 36.7 \\
\hline & Total & 264 & 100.0 \\
\hline \multirow[t]{5}{*}{ Age } & $20-30$ & 117 & 44.3 \\
\hline & $30-40$ & 104 & 39.4 \\
\hline & $40-50$ & 31 & 11.7 \\
\hline & $>50$ & 12 & 4.5 \\
\hline & Total & 264 & 100.0 \\
\hline \multirow{4}{*}{$\begin{array}{l}\text { Number } \\
\text { of family } \\
\text { members }\end{array}$} & $\leqq 3$ & 158 & 59.8 \\
\hline & 4 & 74 & 28.0 \\
\hline & $\geq 5$ & 32 & 12.1 \\
\hline & Total & 264 & 100.0 \\
\hline \multirow{4}{*}{$\begin{array}{c}\text { Company } \\
\text { size }\end{array}$} & Small & 84 & 31.8 \\
\hline & Medium & 110 & 41.7 \\
\hline & Large & 70 & 26.5 \\
\hline & Total & 264 & 100.0 \\
\hline \multirow{3}{*}{$\begin{array}{c}\text { Local } \\
\text { company }\end{array}$} & No & 53 & 20.1 \\
\hline & Yes & 211 & 79.9 \\
\hline & Total & 264 & 100.0 \\
\hline \multirow{5}{*}{$\begin{array}{l}\text { Areas } \\
(\mathrm{m} 2)\end{array}$} & $\leqq 60$ & 9 & 3.4 \\
\hline & $61-90$ & 71 & 27.2 \\
\hline & $91-120$ & 103 & 38.9 \\
\hline & $>120$ & 81 & 30.6 \\
\hline & Total & 264 & 100.0 \\
\hline \multirow{5}{*}{$\begin{array}{l}\text { Contract } \\
\text { amount } \\
\text { (thousand } \\
\text { RMB) }\end{array}$} & $\leqq 50$ & 30 & 11.3 \\
\hline & $60-100$ & 82 & 31.3 \\
\hline & $110-150$ & 96 & 36.2 \\
\hline & $\geq 160$ & 56 & 21.1 \\
\hline & Total & 264 & 100.0 \\
\hline \multirow{5}{*}{$\begin{array}{c}\text { Duration } \\
\text { (days) }\end{array}$} & $\leqq 60$ & 41 & 15.5 \\
\hline & $61-90$ & 130 & 49.1 \\
\hline & $91-120$ & 63 & 24.2 \\
\hline & $>120$ & 30 & 11.3 \\
\hline & Total & 264 & 100.0 \\
\hline
\end{tabular}


Table 2: Measurement model evaluation

\begin{tabular}{|c|c|c|c|c|}
\hline Code & Indicators & Loading & T value & Parameters \\
\hline PRK1 & $\begin{array}{l}\text { I have sufficient knowledge about the finishes, } \\
\text { materials }\end{array}$ & 0.9451 & 32.8936 & \multirow{3}{*}{$\begin{array}{l}\text { Project-related } \\
\text { knowledge, } \\
\mathrm{CR}=0.9472, \\
\mathrm{AVE}=0.8568, \\
\text { Cronbach's } \\
\text { Alpha }=0.9191\end{array}$} \\
\hline PRK2 & $\begin{array}{l}\text { I have sufficient knowledge about the } \\
\text { construction method }\end{array}$ & 0.939 & 23.4497 & \\
\hline PRK3 & $\begin{array}{l}\text { I have sufficient knowledge about the } \\
\text { operational procedures of dwelling fit-out } \\
\text { projects. }\end{array}$ & 0.8919 & 18.7802 & \\
\hline PLE1 & $\begin{array}{l}\text { When conflicts arise, the legal system protects } \\
\text { our interests }\end{array}$ & 0.9237 & 68.8703 & \multirow{2}{*}{$\begin{array}{l}\text { Perceived legal } \\
\text { enforceability, } \\
\text { CR }=0.9155, \\
\text { AVE }=0.8441, \\
\text { Cronbach's } \\
\text { Alpha }=0.8155\end{array}$} \\
\hline PLE2 & $\begin{array}{l}\text { The legal system could restrain contractor's } \\
\text { cheating and fraud behaviors }\end{array}$ & 0.9138 & 51.5737 & \\
\hline $\mathrm{OC} 1$ & $\begin{array}{l}\text { I specify the performance standards in contract } \\
\text { which is seen as the basis for monitoring }\end{array}$ & 0.8901 & 51.6635 & \multirow{3}{*}{$\begin{array}{l}\text { Outcome } \\
\text { control, } \\
\mathrm{CR}=0.8974, \\
\mathrm{AVE}=0.745, \\
\text { Cronbach's } \\
\text { Alpha=0.8302 } \\
\end{array}$} \\
\hline OC2 & $\begin{array}{l}\text { I specify the deadlines which are seen as basis } \\
\text { for controlling }\end{array}$ & 0.8907 & 55.7438 & \\
\hline OC3 & $\begin{array}{l}\text { I strictly control and monitor the } \\
\text { accomplishment of the targets }\end{array}$ & 0.8058 & 20.393 & \\
\hline SC1 & Participatory decision-making & 0.7838 & 22.3061 & \multirow{5}{*}{$\begin{array}{l}\text { Social control, } \\
\text { CR }=0.8921, \\
\text { AVE }=0.6233, \\
\text { Cronbach's } \\
\text { Alpha }=0.849\end{array}$} \\
\hline $\mathrm{SC2}$ & Joint problem solving & 0.7985 & 27.2038 & \\
\hline SC3 & Fine-grained information exchange & 0.8113 & 28.6867 & \\
\hline $\mathrm{SC} 4$ & $\begin{array}{l}\text { When unexpected situation arises, we would } \\
\text { rather work out a new deal than hold each } \\
\text { other to the original terms }\end{array}$ & 0.7844 & 24.4093 & \\
\hline SC5 & $\begin{array}{l}\text { We are open to modifying the agreements if } \\
\text { unexpected events occur }\end{array}$ & 0.7689 & 31.0991 & \\
\hline $\mathrm{BC} 1$ & $\begin{array}{l}\text { I check all material brands and quality } \\
\text { delivered to the site in person }\end{array}$ & 0.9129 & 4.0239 & \multirow{3}{*}{$\begin{array}{l}\text { Behavior } \\
\text { control, } \\
\mathrm{CR}=0.8077, \\
\mathrm{AVE}=0.5888, \\
\text { Cronbach's } \\
\text { Alpha }=0.7142\end{array}$} \\
\hline $\mathrm{BC} 2$ & $\begin{array}{l}\text { I visit site frequently in order to monitor } \\
\text { contractor's behavior }\end{array}$ & 0.7265 & 3.4164 & \\
\hline $\mathrm{BC} 3$ & $\begin{array}{l}\text { I request the contractor to update progress } \\
\text { information on a regular basis }\end{array}$ & 0.6368 & 2.8623 & \\
\hline QPA1 & $\begin{array}{l}\text { It is difficult to observe all quality problems } \\
\text { through inspecting and monitoring }\end{array}$ & 0.8885 & 42.5044 & \multirow{4}{*}{$\begin{array}{l}\text { Quality } \\
\text { performance } \\
\text { ambiguity, } \\
\mathrm{CR}=0.912, \\
\mathrm{AVE}=0.7232, \\
\text { Cronbach's } \\
\text { Alpha }=0.8707\end{array}$} \\
\hline QPA2 & $\begin{array}{l}\text { It is difficult to determine whether quality } \\
\text { problem is attributable to the contractor }\end{array}$ & 0.9013 & 46.3289 & \\
\hline QPA3 & $\begin{array}{l}\text { It is difficult to assess whether contractor is } \\
\text { compliance with the contractual procedures } \\
\text { and construction methods }\end{array}$ & 0.8827 & 45.6729 & \\
\hline QPA4 & $\begin{array}{l}\text { It is difficult to assess whether the information } \\
\text { provided by contractor is reliable }\end{array}$ & 0.7155 & 8.2749 & \\
\hline
\end{tabular}

\section{Note:}

a: $\quad$ T-values for a two-tailed test are 1.65 (significance level $=10 \%), 1.96($ significance level $=5 \%)$ and 2.58 (significance level $=1 \%$ );

b: CR: Composite Reliability 
Table 3: Correlation matrix and square root of AVE of factors

\begin{tabular}{|l|l|l|l|l|l|l|}
\hline Code & QPA & BC & PRK & PLE & OC & SC \\
\hline QPA & $\mathbf{0 . 8 5 0 4}$ & & & & & \\
\hline BC & -0.1729 & $\mathbf{0 . 7 6 7 3}$ & & & & \\
\hline PRK & -0.1631 & 0.2142 & $\mathbf{0 . 9 2 5 6}$ & & & \\
\hline PLE & -0.2541 & 0.2792 & 0.1698 & $\mathbf{0 . 9 1 8 7}$ & & \\
\hline OC & -0.3032 & 0.5218 & 0.1726 & 0.5425 & $\mathbf{0 . 8 6 3 1}$ & \\
\hline SC & -0.3023 & 0.5723 & 0.1865 & 0.4836 & 0.5839 & $\mathbf{0 . 7 8 9 5}$ \\
\hline
\end{tabular}

Note: Bolded numbers are square roots of AVE

Table 4: Cross loadings for individual measurement items

\begin{tabular}{|l|r|r|r|r|r|r|}
\hline Code & \multicolumn{1}{|l}{ PRK } & \multicolumn{1}{|l}{ PLE } & \multicolumn{1}{l|}{ QPA } & \multicolumn{1}{l|}{ BC } & \multicolumn{1}{l|}{ OC } & \multicolumn{1}{l|}{ SC } \\
\hline PRK1 & $\mathbf{0 . 9 3 9}$ & 0.1237 & -0.1431 & 0.1733 & 0.1399 & 0.1155 \\
\hline PRK2 & $\mathbf{0 . 8 9 1 9}$ & 0.1843 & -0.1641 & 0.1419 & 0.1123 & 0.1555 \\
\hline PRK3 & $\mathbf{0 . 9 4 5 1}$ & 0.1634 & -0.1493 & 0.2501 & 0.2026 & 0.2208 \\
\hline PLE1 & 0.1551 & $\mathbf{0 . 9 2 3 7}$ & -0.223 & 0.271 & 0.5231 & 0.4411 \\
\hline PLE2 & 0.1571 & $\mathbf{0 . 9 1 3 8}$ & -0.2447 & 0.2412 & 0.4725 & 0.4478 \\
\hline QPA1 & -0.0862 & -0.2592 & $\mathbf{0 . 8 8 8 5}$ & -0.1478 & -0.2832 & -0.2733 \\
\hline QPA2 & -0.1629 & -0.2286 & $\mathbf{0 . 9 0 1 3}$ & -0.1736 & -0.2654 & -0.2876 \\
\hline QPA3 & -0.215 & -0.1829 & $\mathbf{0 . 8 8 2 7}$ & -0.1692 & -0.2833 & -0.2531 \\
\hline QPA4 & -0.0765 & -0.1934 & $\mathbf{0 . 7 1 5 5}$ & -0.0822 & -0.1857 & -0.2067 \\
\hline BC1 & 0.1811 & 0.3202 & -0.2728 & $\mathbf{0 . 9 1 2 9}$ & 0.5314 & 0.5754 \\
\hline BC2 & 0.1692 & 0.0809 & 0.0421 & $\mathbf{0 . 7 2 6 5}$ & 0.2595 & 0.3401 \\
\hline BC3 & 0.1627 & 0.1116 & 0.0478 & $\mathbf{0 . 6 3 6 8}$ & 0.2911 & 0.2904 \\
\hline OC1 & 0.2088 & 0.5218 & -0.3193 & 0.4535 & $\mathbf{0 . 8 9 0 1}$ & 0.5633 \\
\hline OC2 & 0.0816 & 0.4971 & -0.2364 & 0.4196 & $\mathbf{0 . 8 9 0 7}$ & 0.4926 \\
\hline OC3 & 0.1526 & 0.3632 & -0.2164 & 0.4942 & $\mathbf{0 . 8 0 5 8}$ & 0.4429 \\
\hline SC1 & 0.189 & 0.4014 & -0.2446 & 0.47 & 0.4986 & $\mathbf{0 . 7 8 3 8}$ \\
\hline SC2 & 0.0779 & 0.3937 & -0.1864 & 0.4287 & 0.4336 & $\mathbf{0 . 7 9 8 5}$ \\
\hline SC3 & 0.0784 & 0.4063 & -0.2071 & 0.4248 & 0.4861 & $\mathbf{0 . 8 1 1 3}$ \\
\hline SC4 & 0.2155 & 0.3145 & -0.2382 & 0.4844 & 0.4712 & $\mathbf{0 . 7 8 4 4}$ \\
\hline SC5 & 0.1738 & 0.384 & -0.3081 & 0.4512 & 0.4148 & $\mathbf{0 . 7 6 8 9}$ \\
\hline Note High & & & & & \\
\hline
\end{tabular}

Note: Highest loadings are shown in bold. 
Table 5: Structural model evaluation and hypothesis testing results

\begin{tabular}{|l|l|l|l|l|l|}
\hline Code & Path & Mean & Std. Deviation & T-value & Inference \\
\hline $\mathrm{H}_{1 \mathrm{a}}$ & PRL->OC & 0.0667 & 0.0573 & 1.0823 & n.s. \\
\hline $\mathbf{H}_{\mathbf{1 b}}$ & PRL-> BC & $\mathbf{0 . 1 5 9 5}$ & $\mathbf{0 . 0 8 0 7}$ & $\mathbf{1 . 9 9 3 3}$ & Supported \\
\hline $\mathrm{H}_{1 \mathrm{c}}$ & PRL-> SC & 0.0911 & 0.0541 & 1.5732 & n.s. \\
\hline $\mathbf{H}_{2 \mathbf{a}}$ & PLE->OC & $\mathbf{0 . 4 8 8 7}$ & $\mathbf{0 . 0 5 5 9}$ & $\mathbf{8 . 7 4 4 5}$ & Supported \\
\hline $\mathbf{H}_{2 \mathbf{b}}$ & PLE->BC & $\mathbf{0 . 2 1 6 6}$ & $\mathbf{0 . 0 9 0 6}$ & $\mathbf{2 . 5 3 2 6}$ & Supported \\
\hline $\mathbf{H}_{2 \mathbf{c}}$ & PLE->SC & $\mathbf{0 . 4 2 2 3}$ & $\mathbf{0 . 0 5 8 2}$ & $\mathbf{7 . 2 6 6}$ & Not supported \\
\hline $\mathbf{H}_{3 \mathbf{a}}$ & QPA->OC & $\mathbf{- 0 . 1 7 0 9}$ & $\mathbf{0 . 0 4 7 5}$ & $\mathbf{3 . 5 5 4 6}$ & Supported \\
\hline $\mathrm{H}_{3 \mathrm{~b}}$ & QPA->BC & -0.0859 & 0.1394 & 0.6342 & n.s. \\
\hline $\mathbf{H}_{3 \mathbf{c}}$ & QPA->SC & $\mathbf{- 0 . 1 8 2 8}$ & $\mathbf{0 . 0 6 0 7}$ & $\mathbf{2 . 9 8 0 9}$ & Not supported \\
\hline
\end{tabular}

Note:

a: n.s.: non-significant; not supported denotes that the hypothesis is not accepted in the hypothesized sign.

b: critical t-values for a two-tailed test are 1.65 (significance level $=10$ percent), 1.96 (significance level $=5$ percent $)$, and 2.58 (significance level $=1$ percent $)$. 